\title{
Phosphorus Fertilizer Rating and Rhizobia Inoculation for Improved Productivity of Cowpea in Northern Uganda
}

\author{
S. M. Nyamaizi1,2*, J. B. Tumuhairwe ${ }^{3}$, R. Amayo ${ }^{4}$, C. L. Tumuhe5,6, E. Tereka ${ }^{3}$, D. L. Nabirye ${ }^{3}$, \\ B. B. Obaa ${ }^{3}$
}

${ }^{1}$ Agassiz Research and Development Centre, Agriculture and Agri-Food, Agassiz, BC, Canada

${ }^{2}$ Faculty of Land and Food Systems, The University of British Columbia, Vancouver BC, Canada

${ }^{3}$ Department of Agricultural Production, College of Agricultural and Environmental Sciences, Makerere University, Kampala, Uganda

${ }^{4}$ Department of Crop Production and Management, Faculty of Agriculture and Animal Sciences, Busitema University, Tororo, Uganda

${ }^{5}$ Department of Environmental Management, Makerere University, Kampala, Uganda

${ }^{6}$ African Rural University, Kagadi, Uganda

Email: *sylvia.nyamaizi@canada.ca

How to cite this paper: Nyamaizi, S.M., Tumuhairwe, J.B., Amayo, R., Tumuhe, C.L., Tereka, E., Nabirye, D.L. and Obaa, B.B. (2020) Phosphorus Fertilizer Rating and Rhizobia Inoculation for Improved Productivity of Cowpea in Northern Uganda. American Journal of Plant Sciences, 11, 1505-1519.

https://doi.org/10.4236/ajps.2020.119109

Received: August 14, 2020

Accepted: September 26, 2020

Published: September 29, 2020

Copyright ( 2020 by author(s) and Scientific Research Publishing Inc. This work is licensed under the Creative Commons Attribution International License (CC BY 4.0).

http://creativecommons.org/licenses/by/4.0/ (c) (i) Open Access

\begin{abstract}
Cowpea (Vigna unguiculata) is an important legume crop in the tropics and subtropical regions of the world. It is mainly grown for its leaves and grains, and to a lesser extent as a fodder crop. Cowpea is considered as the most important food grain legume in the dry savannas of tropical Africa. This study compared the yield of local (Agondire) and improved (SECOW 2W) cowpea varieties grown on an Oxisol. Inorganic $P$ at levels of $0,10,20$, and $40 \mathrm{~kg} \cdot \mathrm{ha}^{-1}$ was tested on each variety with or without rhizobia inoculation. The experiments were set up in a randomized complete block design and replicated thrice during the short and long rains of the 2015/2016 seasons on fifteen fields in Arua district, northern Uganda. Agondire responded significantly ( $\mathrm{P}$ $<0.05)$ better than SECOW $2 \mathrm{~W}$ when high rates of inorganic phosphorus $(40$ $\mathrm{kg} \mathrm{P} \mathrm{ha}{ }^{-1}$ ) were applied. A significant increase of $26.4 \%$ and $28.4 \%$ in grain yield of Agondire and SECOW 2W, respectively was obtained after inoculation with rhizobia. We concluded that inoculation and $\mathrm{P}$ fertilizer application increased the yield of both varieties, but with inoculation, SECOW $2 \mathrm{~W}$ performs much better at lower P fertilizer rates than Agondire. Therefore, we recommend growing of SECOW $2 \mathrm{~W}$ under inoculation with $20 \mathrm{~kg} \mathrm{P} \mathrm{ha}^{-1}$ and an application of $40 \mathrm{~kg} \mathrm{P} \mathrm{ha}^{-1}$ for Agondire local cowpea variety in northern Uganda.
\end{abstract}




\section{Keywords}

Phosphorus Fertilizer, Rhizobia Inoculation, Agondire, SECOW 2W, Yield

\section{Introduction}

Cowpea (Vigna unguiculata) is a tropical, annual herbaceous legume that belongs to the family Papilionacea (Fabaceae), order Leguminosae and genus Vigna [1]. It is an important component of agricultural food crops consumed by smallholder farming households. Cowpea plays an important role in achieving food security [2]. It is highly nutritive, having dry matter content of $91 \%$ with Iron, Zinc, and Calcium up to $363,32.2$ and $1112.9 \mathrm{mg} \cdot \mathrm{kg}^{-1}$ respectively, and globulin proteins [3]. The crop is capable of bridging malnutrition and hunger periods since it matures fast and its leaves and grains are edible.

It is estimated that about 14 million hectares of land are globally under cowpea annually [2]. In Africa, the average production area annually under cowpea is over 12.5 million hectares [4]. In sub-Saharan Africa (SSA), the total area harvested for all food legume crops totaled 20 million hectares by 2006-2008 of which 54\% was under cowpea [2]. In Uganda, 11,000 MT from 23,800 ha was harvested in the same period. From this production, $51.5 \%$ was consumed at production household level, $20.7 \%$ sold while $18.5 \%$ was stored for seed [5]. Cowpea is consumed by about 200 million people in Africa making it a very important legume [6].

On-farm yields of cowpea on smallholder farmlands have remained low [6] [7]. For example, between $50 \mathrm{~kg} \cdot \mathrm{ha}^{-1}$ and $500 \mathrm{~kg} \cdot \mathrm{ha}^{-1}$ attained on-farm is in marked contrast to over $2000 \mathrm{~kg} \cdot \mathrm{ha}^{-1}$ obtainable at research stations [2] [7] [8]. The low yields of cowpea are due to low soil fertility with $\mathrm{P}$ being the most limiting nutrient [4] [8] [9], which is exacerbated by low adoption of improved cowpea varieties and technologies [4] [10] [11]. Around $10 \mathrm{~kg} \cdot \mathrm{ha}^{-1}$ of starter $\mathrm{N}$ and 13 to $30 \mathrm{~kg} \cdot \mathrm{ha}^{-1} \mathrm{P}$ were reported as a requirement in low fertility soils for some varieties to ably fix atmospheric $\mathrm{N}$ and better yields in other parts of Africa, Rhodesia [12]. Implying that there is a need for inorganic $P$ fertilizers to be incorporated for soils with low $\mathrm{P}$ quantities that lose more $\mathrm{P}$ than it is replenished [8]. Thus, the cultivation of cowpeas will require $\mathrm{P}$ for efficient nodulation and thus nitrogen fixation in the soil [13].

West Nile loamy farmland agro-ecological zone also known as Annual Cropping and Cattle West Nile System located in northern Uganda is a key zone for cowpea. This zone is dominated by Oxisols as mentioned in Arua State of Environment Report of 2015 and characterized as old and highly weathered soils which are generally low in fertility [14]. Low fertility soils have also been reported to have insufficient rhizobia cells for improvement of $\mathrm{N}$ fixation [15]. Increase in $\mathrm{N}$ for plant uptake with rhizobia inoculation could be expected to increase vegetative growth in cowpea [16]. But however, the increase does not 
directly translate in grain yield in cowpea [16]. Phosphorus fertilizer application in P deficient soil increases yield in crops [16] [17] and however, the increase varies with varieties as for cowpeas [18]. Information on the combined effect of inoculation and $\mathrm{P}$ fertilizer on performance of cowpea varieties is limited. A full understanding of the effects of inoculating rhizobia with inorganic P fertilizer application on yield of cowpea is needed.

To address the low yields of cowpea, the National Semi-Arid Resource Research Institute (NaSARRI) of the National Agricultural Research Organization (NARO) has released several cowpea varieties with high yields ranging between 1500 and $2500 \mathrm{~kg} \cdot \mathrm{ha}^{-1}$ [19]. Some of the released varieties include SECOW 2W, SECOW 3B, SECOW 1T, SECOW 5T, and SECOW 4W. However, these varieties do not realize their full potential on-farm due to poor agronomic practices [7]. Even where commercial farmers have attempted to use P fertilizers, there is a paucity of appropriate rates to be used. Besides, the performance of these improved varieties when subjected to different rates of inorganic $\mathrm{P}$ and inoculation across different major cowpea growing agro-ecological zones in Uganda is unknown.

This study, therefore, evaluated the yield capacity of Agondire, a local variety, and SECOW $2 \mathrm{~W}$, an improved variety after inoculation and P fertilizer application at different rates in Oxisols of northern Uganda. This study aimed at providing information on enhancing cowpea productivity to both farmers and research stakeholders including policy makers and cowpea breeding programs in Uganda. Soil characterization considering chemical properties was done prior to experimentation. The assessments were done to identify suitable sites for experimentation. In this study, Leaf Area Index (LAI), Above Ground Biomass (AGB) and grain yield parameters were considered.

\section{Materials and Methods}

\subsection{Study Area}

Arua district is located in the northern part of Uganda at latitude $3{ }^{\circ} 50^{\prime \prime} \mathrm{N}$ and longitude $30^{\circ} 30^{\prime} \mathrm{E}$. It lies in the West Nile Loamy agro-ecological zone of Uganda. It is dominated by Oxisols which cover almost $70 \%$ of the land. The soils are red to brownish owing to the domination of iron oxides, low weatherable minerals, with a uniform texture (USDA Soil taxonomy). An area of around 30\% is covered by Vertisols as expanding black clay minerals, crack when dry and sticky when wet. They have got a high CEC with a high base saturation and are more fertile (USDA Soil Taxonomy) [14]. The district is commonly covered by a sandy soil texture according to Arua State of Environmental Report compiled in 2015.

The area has got two planting seasons determined by rainfall seasons, Season A spreads from March to May with rainfall peaks received in April on average of around $300 \mathrm{~mm}$. Season B begins from September to October with $474 \mathrm{~mm}$ as average monthly rainfall followed by a dry spell from November to February. 
Temperatures range from $25^{\circ} \mathrm{C}$ to $28^{\circ} \mathrm{C}$ with annual mean temperatures of around $26^{\circ} \mathrm{C}-27^{\circ} \mathrm{C}[20]$.

\subsection{Determination of the Soil Chemical Properties of the Study Sites}

Five study sites were selected through a field reconnaissance conducted in mid-January, 2015 in Rhigbo and Rhino camp sub-counties. These are the major areas known for cowpea cultivation. At each site, three thoroughly mixed samples of three blocks at $0-15 \mathrm{~cm}$ and from an underlying $15-30 \mathrm{~cm}$ depth of soil were collected in February 2015 before the start of the planting season. Samples were taken from both previously cultivated cowpea fields and uncultivated soils. The samples were transported to Soil Chemistry Laboratory at the School of Agricultural Sciences Laboratory, Makerere University for further analysis.

A total of 90 composite samples were air-dried at room temperature, crushed using a pestle and motor, and then sieved through a $2 \mathrm{~mm}$ sieve. Chemical analyses done included determination of soil $\mathrm{pH}$, soil organic matter ( $\mathrm{SOM})$, total $\mathrm{N}$, available $\mathrm{P}$, and exchangeable cations following procedures as described by [11]. Soil $\mathrm{pH}$ was determined in a solution of soil to water ratio $(1: 2.5 \mathrm{w} / \mathrm{v})$ using a $\mathrm{pH}$ electrode meter after shaking for one hour and the solution allowed to settle for 30 minutes before readings are taken. Soil Organic Carbon (SOC) was also determined using procedures described in [11].

Total $\mathrm{N}$ was determined using the Kjeldahl method [11]. Available P was extracted using the Bray 1 method and measured calorimetrically. Ammonium acetate was used to extract exchangeable bases $\mathrm{K}^{+}, \mathrm{Mg}^{2+}$, and $\mathrm{Ca}^{2+}$. Concentrations of $\mathrm{Ca}^{2+}$ and $\mathrm{Mg}^{2+}$ were measured using atomic absorption spectrophotometer, whereas $\mathrm{K}^{+}$was measured using a flame photometer. Soil texture was determined using the hydrometer method [11].

\subsection{Experimental Treatment and Design}

The treatments comprised two cowpea varieties (V) tested against $\mathrm{P}$ rates of 0 , 10,20 , and $40 \mathrm{~kg} \mathrm{P} \mathrm{ha}{ }^{-1}$, with or without inoculation (I) arranged in a randomized complete block design with three replicates and repeated in cropping seasons of 2015B, 2016A, and 2016B. The study was conducted in 15 farmers' fields - three fields per site in the five selected sites. The tested cowpea varieties were Agondire (local check). Agondire was selected as one of the predominant (90\%) native variety grown in northern Uganda for the past three decades to date. It is a spreading variety with larger seeds and preferred by farmers due to its higher yield and being resistant to diseases compared to other locally grown varieties. SECOW $2 \mathrm{~W}$ is an improved cowpea variety bred for high yielding.

Inorganic P from Triple Super Phosphate (TSP) was banded by hand at planting per the rates of each treatments in the experimental units. The rhizobia inoculant, Bradyrhizobium Mak-biofixer, obtained from Makerere University Soil Microbiology Laboratory was used throughout the experimentation. To avoid seed mix up and contamination, the treatments for inoculation were 
planted last. A recommended starter dose of $10 \mathrm{~kg} \mathrm{~N}$ [21] in form of ammonium sulphate for legumes was applied by hand broadcasting in all experimental units at planting. The experiments were planted in plot sizes of $36 \mathrm{~m}^{2}(6 \mathrm{~m} \times 6 \mathrm{~m})$ with guard rows of $2 \mathrm{~m}$ wide around each experimental set up. Blocks were separated by a $2 \mathrm{~m}$ distance to enable data collection and execution of field management activities. The varieties were spaced at $1 \mathrm{~m}$ by $1 \mathrm{~m}$ and $60 \mathrm{~cm}$ by $30 \mathrm{~cm}$ for Agondire and SECOW 2W respectively.

The experimental fields were prepared manually using hand hoes. Thinning was done two weeks after planting to one plant per hole and off-types were rogued out by hand. Weeding was done twice at 21 and 45 days after planting. Dimethoate and cypermethrin were sprayed uniformly to all plots to control insect pests.

\subsection{Data Collected}

For all the agronomic parameters measured, data were collected from 10 randomly selected plants per plot located in the inner most rows. Leaf area index (LAI) determination followed procedures described by [22]. Thus, the leaf width (at the widest part of the leaf) and leaf length (from the bottom end of the leaf to leaf apex) were measured using a tape measure and thereafter leaf area (LA) and Leaf Area Index (LAI) determined as shown.

Leaf Area (LA) $=$ crop factor (Leaf width $\times$ Leaf length) and Leaf Area Index $(\mathrm{LAI})=\mathrm{LA} \times$ Number of leaves/Land Area.

Above ground biomass (AGB) at flowering was measured by randomly sampling and cutting three plants per plot and their weights recorded. The samples were oven-dried at $70^{\circ} \mathrm{C}$ for three days. At harvest, the whole plot $(6 \mathrm{~m} \times 6 \mathrm{~m})$ at maturity excluding the guard rows was cut and weighed to record AGB. The recorded weights per plot were converted to $\mathrm{kg} \cdot \mathrm{ha}^{-1}$. The mature pods from the plants in the plot were plucked at harvest, threshed and the seeds were dried to an appropriate moisture content (14\%). The dried seeds per plot were then weighed and used to obtain grain yield $\left(\mathrm{kg} \cdot \mathrm{ha}^{-1}\right)$.

\subsection{Data Handling and Statistical Analysis}

All the data collected were entered in excel spreadsheet and analyzed using Gen.Stat Statistical software 14th edition. Analysis of Variance (ANOVA) was conducted and means obtained were separated at a $95 \%$ confidence interval. All graphs were generated using excel statistical package. The treatment structure, Variety * Inoculation * Phosphorus * Season was tested using ANOVA and (Site

${ }^{\star}$ Rep) was used as the block structure. A comparison of means at $5 \%$ was done using Fisher's Protected Least Significant Difference (L.S.D).

\section{Results}

\subsection{The Soil Chemical Properties at Each Site}

The soil chemical properties of the study sites are presented in Table 1 . The soils 
were slightly acidic with low SOM. Nevertheless, cultivated fields had less SOM (1.0\%) than that of uncultivated sites (1.2\%). The available $\mathrm{P}$ (Bray 1 ) was much lower at all sites averaging between 6.02 and $10.83 \mathrm{mg} \cdot \mathrm{kg}^{-1}$. However, the soil at top depth $0-15 \mathrm{~cm}$ had higher available $P$ than that at $15-30 \mathrm{~cm}$ depth. Similarly, all sites reported lower total $\mathrm{N}$ content for both cultivated and uncultivated sites. Exchangeable bases $\mathrm{K}^{+}, \mathrm{Ca}^{2+}$, and $\mathrm{Mg}^{2+}$ were also lower than minimum amounts required for crop growth.

\subsection{Variation in the Leaf Area Index (LAI)}

The LAI significantly $(\mathrm{P}<0.001)$ varied with variety. Agondire had significantly $(\mathrm{P}<0.001)$ larger LAI of 0.097 than SECOW $2 \mathrm{~W}(0.030)$. Inoculation significantly $(\mathrm{P}<0.001)$ increased LAI with an average 0.206 obtained in inoculated treatments compared to 0.155 from non-inoculated treatments. Similarly, the main effect of $P$ fertilization significantly $(P<0.001)$ increased LAI with the highest LAI of 0.233 obtained at $40 \mathrm{~kg} \mathrm{P} \mathrm{ha}^{-1}$ and least 0.149 at $0 \mathrm{~kg} \mathrm{P} \mathrm{ha}{ }^{-1}$ (LSD $(0.05)=0.03)$. The combined application of $\mathrm{P}$ fertilizer and inoculation with rhizobia significantly $(\mathrm{P}<0.001)$ increased LAI irrespective of the variety. The LAI increased with an increase in the rate of $\mathrm{P}$ with exceptions of a drop at $10 \mathrm{~kg}$ $\mathrm{P} \mathrm{ha}^{-1}$ and $20 \mathrm{~kg} \mathrm{P} \mathrm{ha}^{-1}$ for inoculated and no rhizobia inoculations respectively (Figure 1).

There was also a significant $(\mathrm{P}<0.05)$ effect of combined interaction of variety $(\mathrm{V})$, inoculation (I), and phosphorus (P) fertilization on LAI. However, irrespective of inoculation, SECOW $2 \mathrm{~W}$ recorded larger LAI than Agondire including the highest $\mathrm{P}$ rates (Table 2).

Table 1. Chemical properties of soil from cultivated and uncultivated soil at $0-15 \mathrm{~cm}$ and $15-30 \mathrm{~cm}$ for five trial areas in Arua district.

\begin{tabular}{|c|c|c|c|c|c|c|c|}
\hline Soil property & $\begin{array}{l}{ }^{*} \text { Critical } \\
\text { values }\end{array}$ & Cultivated & Fields & Uncultivated & Fields & $\operatorname{LSD}_{(0.05)}$ & $\begin{array}{l}\mathrm{CV} \\
(\%)\end{array}$ \\
\hline Depth & & $0-15 \mathrm{~cm}$ & $15-30 \mathrm{~cm}$ & $0-15 \mathrm{~cm}$ & $15-30 \mathrm{~cm}$ & & \\
\hline $\mathrm{pH}$ & 5.50 & 6.50 & 6.30 & 6.90 & 6.40 & & \\
\hline S0M (\%) & 3.00 & 1.07 & 0.93 & 1.29 & 1.06 & 0.203 & 9.9 \\
\hline Total N (\%) & 0.25 & 0.12 & 0.10 & 0.11 & 0.13 & 0.021 & 11.8 \\
\hline $\begin{array}{l}\text { Available } \\
\mathrm{P}\left(\mathrm{mgkg}^{1}\right)\end{array}$ & 15.00 & 10.83 & 6.02 & 7.77 & 7.97 & 3.900 & 31.1 \\
\hline \multicolumn{8}{|c|}{ Exchangeable cations $\mathrm{cmol} \mathrm{kg}^{-1}$} \\
\hline $\mathrm{K}^{+}$ & 0.78 & 0.39 & 0.33 & 0.39 & 0.36 & 0.07 & 11.7 \\
\hline $\mathrm{Ca}^{2+}$ & 8.60 & 4.17 & 3.69 & 3.97 & 3.87 & 0.67 & 4.0 \\
\hline $\mathrm{Mg}^{2+}$ & 2.15 & 1.95 & 1.59 & 2.04 & 1.78 & 0.34 & 10.5 \\
\hline
\end{tabular}

* [11] [23]. 
Table 2. Leaf area index (LAI) $\left(\mathrm{m}^{2} \mathrm{~m}^{-2}\right)$ of cowpea varieties following inoculation and phosphorus fertilizer application.

\begin{tabular}{cccccc}
\hline Variety & Agondire & \multicolumn{3}{c}{ SECOW 2W } & LSD $_{(0.05)}$ \\
\hline P rate $\left(\mathrm{kgha}^{-1}\right)$ & No inoculation & Inoculated & No inoculation & Inoculated & $\left(\mathrm{V}^{\star} \mathrm{I}\right)=0.036$ \\
\hline 0 & 0.062 & 0.086 & 0.164 & 0.287 & $\left(\mathrm{~V}^{*} \mathrm{P}\right)=0.043$ \\
10 & 0.095 & 0.090 & 0.255 & 0.248 & \\
20 & 0.057 & 0.101 & 0.254 & 0.261 & \\
40 & 0.106 & 0.183 & 0.250 & 0.391 & \\
$\mathrm{LSD}\left(\mathrm{V}^{*} \mathrm{P}^{*} \mathrm{I}\right)$ & & & & & 0.031 \\
$\mathrm{CV}(\%)$ & & & & & 9.900 \\
\hline
\end{tabular}

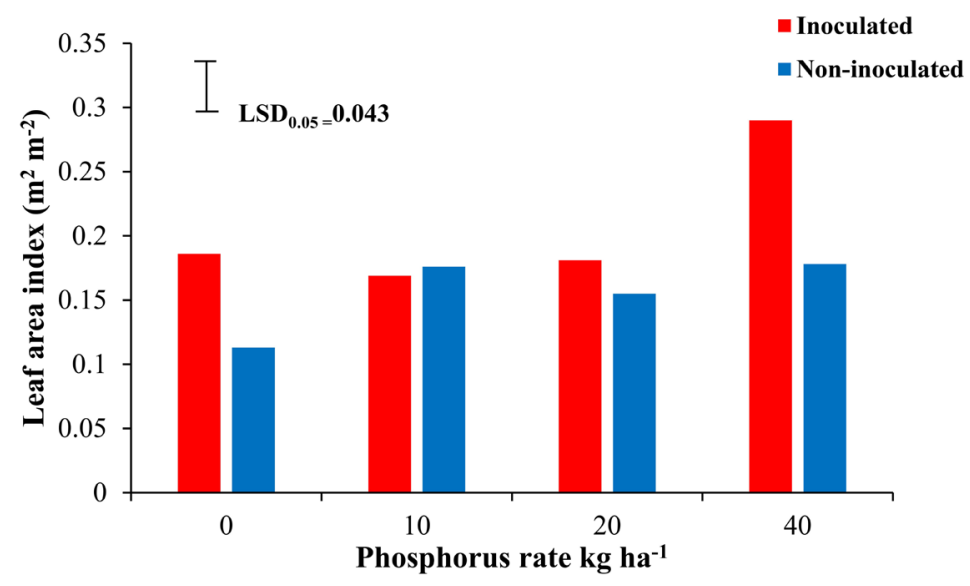

Figure 1. Leaf Area Index under a combination of inoculation and phosphorus application in a cowpea study in Uganda.

\subsection{Variations in Above-Ground Biomass (AGB)}

Regardless of the cowpea variety, inoculation significantly $(\mathrm{P}<0.001)$ increased AGB for the crop at flowering. An average of $4229 \mathrm{~kg} \cdot \mathrm{ha}^{-1}$ was obtained in inoculated treatments compared to $3236 \mathrm{~kg} \cdot \mathrm{ha}^{-1}(\operatorname{LSD}(0.05)=238)$ from non-inoculated treatments. Similarly, phosphorus fertilizer application significantly $(p<0.001)$ increased AGB at flowering and harvest irrespective of variety. The AGB increased with an increase in $\mathrm{P}$ fertilizer unit addition, AGB at $\mathrm{P} 0<$ $\mathrm{P} 10<\mathrm{P} 20<\mathrm{P} 40$ (Figure 2).

There was a significant $(\mathrm{P}<0.001)$ effect of the interaction of variety, inoculation, and phosphorus fertilization on AGB at flowering. Agondire had the highest biomass at $40 \mathrm{~kg} \mathrm{P} \mathrm{ha}{ }^{-1}$ while SECOW $2 \mathrm{~W}$ had the highest at $20 \mathrm{~kg} \mathrm{P} \mathrm{ha}{ }^{-1}$ without inoculation. SECOW $2 \mathrm{~W}$ recorded smaller biomass at flowering than Agondire at $\mathrm{P}$ rate of 0 and $40 \mathrm{~kg} \mathrm{P} \mathrm{ha}^{-1}$. Inoculation increased the AGB at flowering alongside with $\mathrm{P}$ fertilizer rates for Agondire (Table 3).

The above-ground biomass at harvest significantly $(\mathrm{P}<0.001)$ increased with inoculation. Cowpeas under inoculated treatments realized average AGB of 4404 $\mathrm{kg} \cdot \mathrm{ha}^{-1}$ compared to $3829 \mathrm{~kg} \cdot \mathrm{ha}^{-1}(\operatorname{LSD}(0.05)=232)$ for those without inocula- 
tion. A significant effect $(\mathrm{P}<0.05)$ of combined inoculation and $\mathrm{P}$ fertilization on AGB at harvesting was observed. An increase in $\mathrm{P}$ applied led to a proportional increment in AGB at harvesting irrespective of inoculation. Both varieties significantly realized more biomass when inoculation was applied in combination with $40 \mathrm{~kg} \mathrm{P} \mathrm{ha}^{-1}$ (Figure 3 ).

The interactive effect of variety, inoculation, and $\mathrm{P}$ fertilizer rate on AGB at harvesting was significant $(\mathrm{P}<0.001)$. Without inoculation, the biomass of both varieties at harvest increased with an increase in the $\mathrm{P}$ rate. On the other hand, it was only Agondire that had a significant increase in biomass following the interaction of $\mathrm{P}$ application and inoculation. Agondire recorded the highest biomass at $40 \mathrm{~kg} \mathrm{P} \mathrm{ha}{ }^{-1}\left(6880 \mathrm{~kg} \cdot \mathrm{ha}^{-1}\right)$ whereas SECOW $2 \mathrm{~W}$ recorded the highest biomass at $20 \mathrm{~kg} \mathrm{P} \mathrm{ha}{ }^{-1}\left(4790 \mathrm{~kg} \cdot \mathrm{ha}^{-1}\right)$ under inoculation (Table 4).

\subsection{Variation in Grain Yield}

Grain yields significantly $(\mathrm{P}<0.001)$ varied between variety. SECOW $2 \mathrm{~W}$ had significantly more grain yield $\left(1148 \mathrm{~kg} \cdot \mathrm{ha}^{-1}\right)$ than Agondire $\left(856 \mathrm{~kg} \cdot \mathrm{ha}^{-1}\right)$. Also, a significant $(\mathrm{P}<0.001)$ effect of inoculation on grain yield was noted. Overall, inoculated fields recorded more yield $\left(1123 \mathrm{~kg} \cdot \mathrm{ha}^{-1}\right)$ than the fields which did not receive inoculum $\left(881 \mathrm{~kg} \cdot \mathrm{ha}^{-1}\right)$. The main effect of $\mathrm{P}$ significantly $(\mathrm{P}<0.001)$ increased grain yield $\left(\mathrm{P}_{40}>\mathrm{P}_{20}>\mathrm{P}_{10}>\mathrm{P}_{0}\right)$ (Figure 4).

Table 3. Above-ground biomass at flowering ( $\mathrm{kg}$ per ha) of the cowpea varieties following inoculation and phosphorus fertilizer application in a cowpea study in Uganda.

\begin{tabular}{cccccc}
\hline Variety & \multicolumn{2}{c}{ Agondire } & \multicolumn{2}{c}{ SECOW 2W } & LSD $_{(0.05)}$ \\
\hline P rate $\left(\mathrm{kgha}^{-1}\right)$ & No inoculation & Inoculated & No inoculation & Inoculated & $\left(\mathrm{V}^{\star} \mathrm{I}\right)=337$ \\
\hline 0 & 3015 & 3164 & 2381 & 3510 & $\left(\mathrm{~V}^{\star} \mathrm{P}\right)=476$ \\
10 & 2849 & 3756 & 3418 & 3455 & \\
20 & 3756 & 3959 & 4491 & 4750 & \\
40 & 4644 & 6660 & 4454 & 4583 & \\
$\mathrm{LSD}\left(\mathrm{V}^{*} \mathrm{P}^{\star} \mathrm{I}\right)$ & & & & & 674 \\
$\mathrm{CV}(\%)$ & & & & & 26.0 \\
\hline
\end{tabular}

Table 4. Above-ground biomass at harvesting (kg per ha) of different cowpea varieties following inoculation and phosphorous fertilizer application in a cowpea study in Uganda.

\begin{tabular}{|c|c|c|c|c|c|}
\hline Variety & Agondire & & SECOW & $2 \mathrm{~W}$ & $\operatorname{LSD}_{(0.05)}$ \\
\hline $\mathrm{P}$ rate $\left(\mathrm{kg} \cdot \mathrm{ha}^{-1}\right)$ & No inoculation & Inoculated & No inoculation & Inoculated & $\left(\mathrm{V}^{\star} \mathrm{I}\right)=328$ \\
\hline 0 & 3046 & 3491 & 2713 & 3704 & $\left(\mathrm{~V}^{\star} \mathrm{P}\right)=464$ \\
\hline 10 & 3093 & 3833 & 3574 & 3585 & \\
\hline 20 & 4056 & 4250 & 4537 & 4790 & \\
\hline 40 & 4880 & 6880 & 4731 & 4749 & \\
\hline $\operatorname{LSD}\left(\mathrm{V}^{\star} \mathrm{P}^{\star} \mathrm{I}\right)$ & & & & & 657 \\
\hline CV (\%) & & & & & 24.3 \\
\hline
\end{tabular}




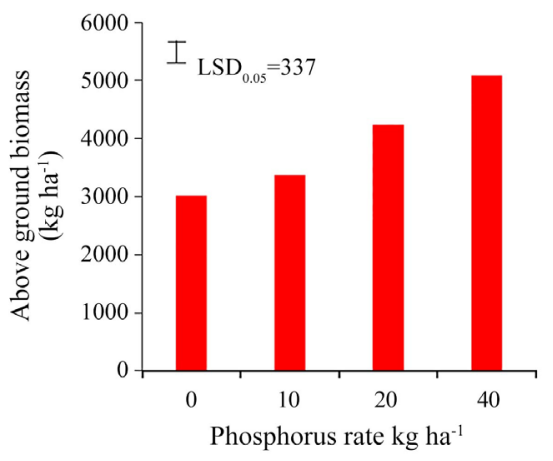

(a)

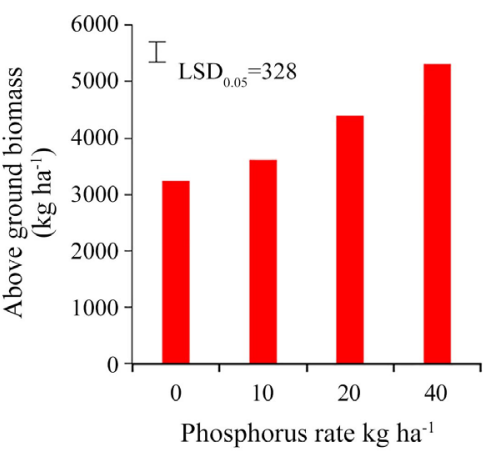

(b)

Figure 2. Above-ground biomass at flowering (a) and harvesting (b) under different phosphorous application rates in a cowpea study in Uganda.

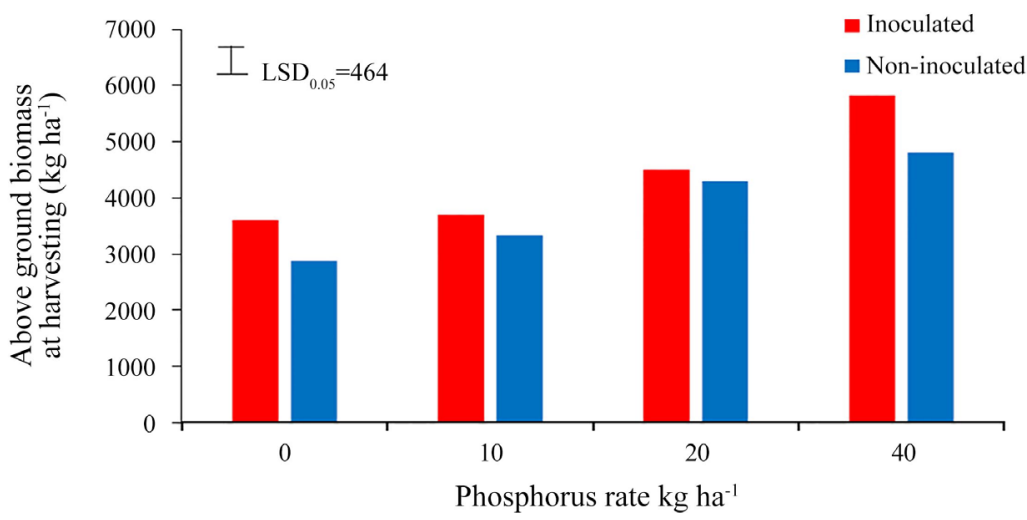

Figure 3. Above-ground biomass (kg per ha) at harvesting as affected by the interaction of inoculation and phosphorous application in a cowpea study in Uganda.

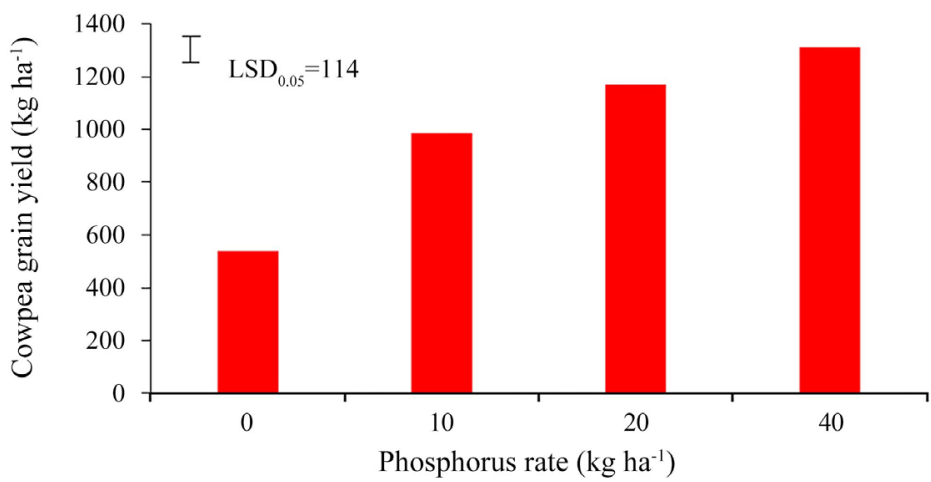

Figure 4. Cowpea grain yield under the different rates of phosphorus application in a cowpea study in Uganda.

A significant $(\mathrm{P}<0.001)$ increase in grain yield was observed for interaction between variety and inoculation interaction. However, the increase is larger in SECOW 2W than Agondire (Figure 5). Similarly, grain yield significantly $(\mathrm{P}<$ 0.001 ) increased with the combined effect of variety and $\mathrm{P}$ fertilizer application (Figure 6). Grain yield also increased with $P$ fertilizer rate except for SECOW $2 \mathrm{~W}$ at $40 \mathrm{~kg} \mathrm{P} \mathrm{ha}^{-1}$.

The interactive effect of inorganic $P$ fertilizer rate and inoculation on grain 
yield was significant. Irrespective of inoculation, the increment in rates of $\mathrm{P}$ fertilizer led to an increase in grain yield, except at $40 \mathrm{~kg} \mathrm{P} \mathrm{ha}^{-1}$ under inoculation where there was a slight drop (Figure 7).

Interactive effect of the variety grown, inoculation, and $\mathrm{P}$ fertilizer rate on grain yield was significant and resulted in an increase in grain yield (Table 5). However, for SECOW $2 \mathrm{~W}$ the grain yield increased with an increase in P rate up to $20 \mathrm{~kg} \mathrm{P} \mathrm{ha}^{-1}$ and declined thereafter. Irrespective of inoculation, SECOW $2 \mathrm{~W}$ recorded higher grain yield than Agondire at 0, 10, and $20 \mathrm{~kg} \mathrm{P} \mathrm{ha}^{-1}$ whereas Agondire recorded higher yield at $40 \mathrm{~kg} \mathrm{P} \mathrm{ha}^{-1}$ (Table 5).

Table 5. Grain yield (kg per ha) of local and improved cowpea varieties following inoculation and phosphorus fertilizer application in a cowpea study in Uganda.

\begin{tabular}{cccccc}
\hline Variety & \multicolumn{2}{c}{ Agondire } & \multicolumn{2}{c}{ SECOW 2W } & LSD $_{(0.05)}$ \\
\hline P rate $\left(\mathrm{kg}^{\mathrm{h}} \mathrm{ha}^{-1}\right)$ & No inoculation & Inoculated & No inoculation & Inoculated & $\left(\mathrm{V}^{\star} \mathrm{I}\right)=111.4$ \\
\hline 0 & 448 & 508 & 571 & 631 & $\left(\mathrm{~V}^{\star} \mathrm{P}\right)=157.6$ \\
10 & 552 & 872 & 903 & 1617 & \\
20 & 600 & 1029 & 1350 & 1705 & \\
40 & 1423 & 1415 & 1198 & 1211 & \\
$\mathrm{LSD}\left(\mathrm{V}^{\star} \mathrm{P}^{\star} \mathrm{I}\right)$ & & & & & 222.0 \\
$\mathrm{CV}(\%)$ & & & & & 12.8 \\
\hline
\end{tabular}

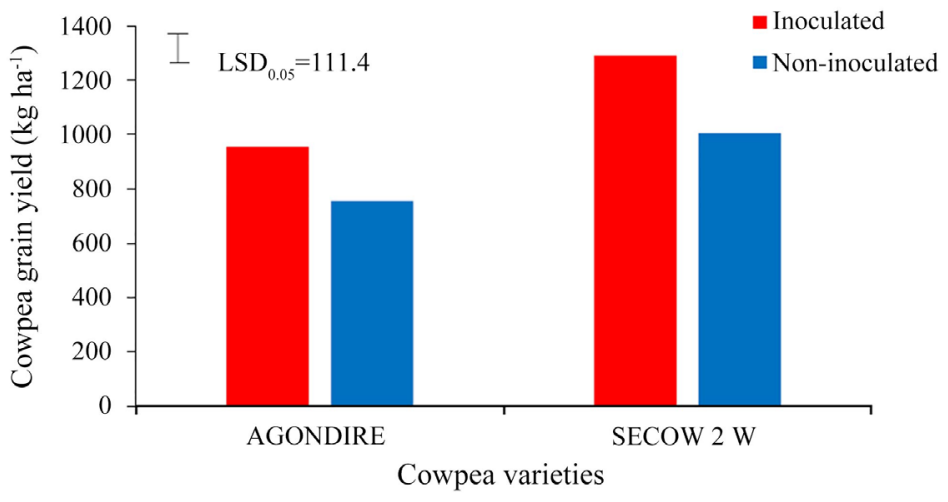

Figure 5. Cowpea varietal grain yield under the influence of inoculation as obtained in a cowpea study in Uganda.

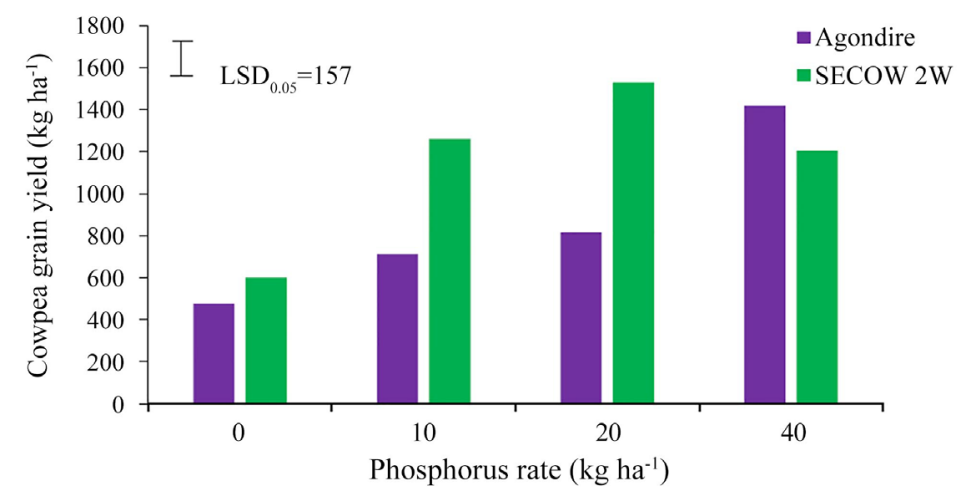

Figure 6. Cowpea varietal grain yield under different rates of phosphorous application in a cowpea study in Uganda. 


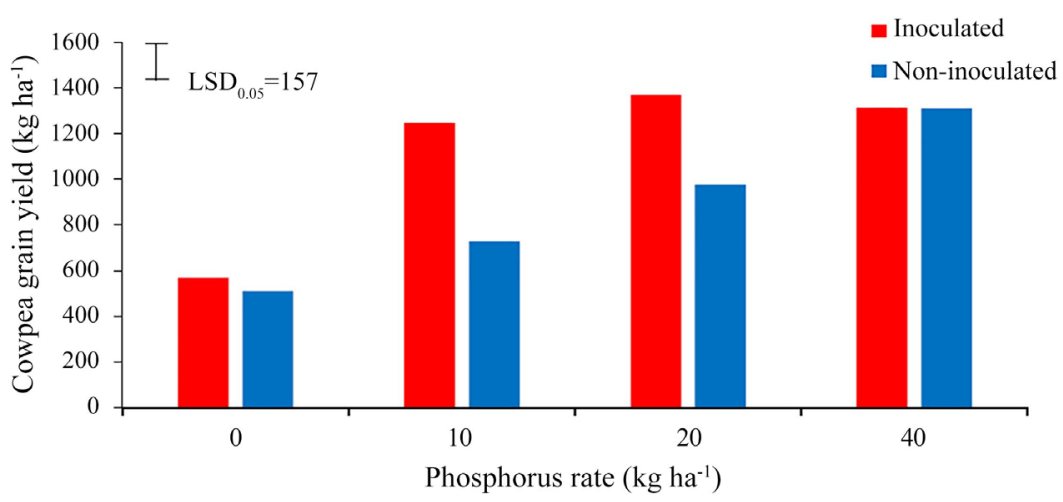

Figure 7. Cowpea grain yield under the combined effect of inoculation and phosphorus fertilizer application in a cowpea study in Uganda.

\section{Discussion}

Preliminary soil characterization in this study crucially led to proper experimental site selection in northern Uganda. The sites had slightly acidic soils which favor most nutrient availability [12] and crop growth [24]. However, the soils had low soil organic matter and low fertility confirming to the existence of Oxisols. For all major nutrients, $\mathrm{N}$ (Kjhedhal) and $\mathrm{P}$ (Bray 1) were limiting below the critical minimum ( $15 \mathrm{mg} \mathrm{kg}^{-1}$ available $\mathrm{P}$ ) required for cropping in East Africa [11]. However, cowpea has been reported to grow well in low fertility soils with limiting nutrients when compared to other crops [21].

Leaf area index (LAI) was averagely small across all sites. Likely, hot weather in the sites during 2015/2016 planting seasons could have been the reason for small LAI observed in both varieties. According to [25], LAI is greatly affected by hot weather environments. Due to differences originating from varietal phenotypic traits, we mainly considered LAI differences within each variety than between them. The observations were however enhanced by P fertilizer application and inoculation effects being fundamental in this study. Agondire is characteristically a spreading variety with wide branches and hence anchor many leaves on them which positively contributed to larger LAI. On the other hand, SECOW $2 \mathrm{~W}$ is an erect variety with non-spreading branches that anchor fewer leaves. Higher LAI for Agondire contributed to a larger AGB at flowering and harvest stages. LAI significantly contributes to increased biomass of cowpea [9]. Interestingly, SECOW $2 \mathrm{~W}$ highly responds to rhizobia inoculation than Agondire and hence recorded higher LAI under rhizobia inoculation. It is expected for $\mathrm{N}$ fixation increment with varietal positive responses to rhizobia inoculation which also increases vegetative expansion [16] [26].

Generally, higher yields were recorded in this study than the range often got on-farm (50 - $\left.500 \mathrm{~kg} \cdot \mathrm{ha}^{-1}\right)$. This could ably be attributed to inoculation and $\mathrm{P}$ application [26]. Importantly, though, the yields from all sites were below the attainable on research stations. Both varieties were affected by environmental stresses of unreliable rainfall and high temperatures to over $29^{\circ} \mathrm{C}$ recorded in some days in the planting seasons of 2015/2016. These caused severe water 
stresses in Arua [5] for the crop. Elsewhere, a significant reduction in yield was reported in cowpea grown in stressing environments like hot weather and inadequate rainfall [27].

The higher grain yield for SECOW $2 \mathrm{~W}$ is due to its intrinsic high yield ability than Agondire. Higher grain yield with inoculation for both varieties were attributed to the interplay of parameters like LAI and AGB which increased with inoculation. Yield components such as LAI and dry matter greatly affect grain yield in cowpea [28]. The positive effect of $\mathrm{P}$ on biomass and yield in this study confirms that $\mathrm{P}$ remains a limiting nutrient in most soils in sub-Saharan Africa (SSA) [8] [28]. Phosphorus is an essential nutrient highly needed by legumes like cowpea. It influences flowering, improvement of ADP and ATP energy functions [16] [21] and cowpea yield [8]. The availability of $P$ for uptake also increases photosynthesis [16] [28] and thus boosting yields of cowpea growth and its production in the West Nile Farming system. Earlier studies have reported a significant and positive increase in grain yield of cowpea with an increase in P fertilizer application rate [29]. We also remarkably consider that this study was relevant as contradicting results of $\mathrm{P}$ fertilizer effect on yield have been reported [30].

Application of $\mathrm{P}$ fertilizers together with inoculation increased AGB and grain yield of cowpea, which is consistent with results reported by [8] [17]. They emphasized that the combination of $\mathrm{P}$ application with right strains of rhizobia inoculation increases yield in cowpea. Unlike SECOW 2W, Agondire variety AGB and grain yield increased even at the highest $\mathrm{P}$ rate $\left(40 \mathrm{~kg} \mathrm{P} \mathrm{ha}^{-1}\right)$. It was determined that the local variety requires more $\mathrm{P}$ units than SECOW $2 \mathrm{~W}$. For this result, the differences in morphological structures of the two varieties could also be at play. Grain yield drop observed at higher P rates $\left(40 \mathrm{~kg} \mathrm{P} \mathrm{ha}^{-1}\right)$ for SECOW $2 \mathrm{~W}$ explain other factors that limit cowpea productivity. However, higher amounts of applied P surpassing a variety's requirements could also lead to reduced seed development and subsequently its grain yield [31].

Outstandingly, internal nitrogen utilization efficiency determined for both varieties were $\left(26.9 \mathrm{~kg} \cdot \mathrm{kg}^{-1}\right)$ and $\left(18.2 \mathrm{~kg} \cdot \mathrm{kg}^{-1}\right)$ for SECOW $2 \mathrm{~W}$ and Agondire respectively. This explains that SECOW $2 \mathrm{~W}$ is more efficient in converting nutrients into yield than Agondire and hence required lesser P units for yield recovery. This is similar to [8], where improved varieties tested had better nutrient utilization efficiency than the local spreading varieties. This could further be explained by the early maturing variety ( 80 - 95 days) nature of SECOW $2 \mathrm{~W}$, which is consistent with [21], who reported that quick maturing cowpea varieties are efficient in utilizing available nutrients even at low nutrient levels.

\section{Conclusions}

We conclude that there are marked varietal differences in yield of cowpea. Application of rhizobia inoculation with $\mathrm{P}$ fertilizer application increases cowpea yield in northern Uganda. This study also concludes that there are other factors affecting yielding of cowpea in this region. These could include the 
environmental stresses like unreliable rainfall and hot weather.

SECOW 2W attains its maximum yield at $20 \mathrm{~kg} \mathrm{P} \mathrm{ha}^{-1}$ with inoculation and therefore inoculation of the variety influenced yield. On the other hand, Agondire yield was less affected by inoculation but more by $\mathrm{P}$ fertilizer application attaining its maximum yield at $40 \mathrm{~kg} \mathrm{P} \mathrm{ha}^{-1}$ with or without inoculation. It is concluded that the improved variety requires low rates of $\mathrm{P}$ than the local variety when inoculation with rhizobia is applied.

We recommended that farmers adopt the improved variety such as SECOW $2 \mathrm{~W}$ because it realizes the highest yield at low $\mathrm{P}$ rate than the local variety (Agondire) with and without inoculation. In further studies, there is need of harnessing the native rhizobia strains to match the current commercial rhizobia strain used in this study.

\section{Acknowledgements}

Appreciation goes to Regional Agricultural Forum for Capacity Building in Agriculture (RUFORUM) for funding this research. The authors also acknowledge Makerere University, School of Agricultural Sciences, National Crop Resource Research Institute (NaCRRI), National Semi-Arid Resources Research Institute (NaSARRI) and Arua District Famers Association (ARUDIFA) for the infrastructural and technical support rendered throughout this study.

\section{Conflicts of Interest}

The authors declare no conflicts of interest regarding the publication of this paper.

\section{References}

[1] Adejumo, T.O. (2013) Identification, Incidence, Severity and Methods of Control of the Casual Organism of False Smut Disease of Cowpea Vigna unguiculata L. Walp. African Agricultural Technology Foundation, 2, 313-321.

[2] FAOSTAT (2011) Bulletin of Tropical Legumes. http://www.icrisat.org/tropical

[3] Islam, S.I. Idle, J.R. and Smith, R.L. (1980) The Polymorphic 4-Hydroxylation of Debrisoquin in a Sauda Arabia Population. Journal of Xenobiotica, 10, 819-825. https://doi.org/10.3109/00498258009033812

[4] Singh, B.B., Ajeigbe, H., Tarawali, A.S., Fernandez, R.S. and Abubakar, M. (2003) Improving the Production and Utilization of Cowpea as Food and Fodder. Journal of Field Crops, 84, 169-177. https://doi.org/10.1016/S0378-4290(03)00148-5

[5] Uganda Bureau of Statistics (UBOS) (2012) Arua District Local Government-Climate Rainfall, Temperature and Soils. Arua Local Government and UBOS, Uganda.

[6] Oyewale, O.R., Acad, S., Biosci, J. and Cobley, S. (2013) Introduction to the Botany of Tropical Crops. Longman Group Limited-Essex, Harlow, 79-98.

[7] Orawu, M., Melis, R., Mark Laing, M. and Derera, J. (2012) Genetic Inheritance of Resistance to Cowpea Aphid-Borne Mosaic Virus in Cowpea. Euphytica. International Journal of Plant Breeding, 189, 191-201. https://doi.org/10.1007/s10681-012-0756-3 
[8] Bationo, A., Mtare, B.R., Tarawali, S.A. and Tabo, R. (2000) Soil Fertility Management and Cowpea Production in Semi-Arid Tropics. Proceedings of the World Cowpea Conference III, Ibadan, 4-8 September 2000, 301-318.

[9] Magani, I.E. and Kuchida, C. (2009) Effect of Phosphorus Fertilizer on Growth, Yield and Crude Protein Content on Cowpea (Vigna unguiculata L.Walp) in Nigeria. Journal of Applied Biosciences, 23, 1387-1393.

http://www.biosciences.elewa.org

[10] Kolawale, G.O., Tian, G. and Singh, B.B. (2000) Differential Response of Cowpea Varieties to Aluminum and Phosphorous Application. Journal of Plant Nutrition, 23, 731-740. https://doi.org/10.1080/01904160009382055

[11] Okalebo, J.R, Gathna, K.W. and Woomer, P.L. (2002) Laboratory Methods for Soil and Plant Analysis. A Working Manual. 2nd Edition, Tropical Soil Fertility and Biology Program, Nairobi.

[12] Johnson, D.T. (1970) The Cowpea in the African Areas of Rhodesia. Journal of Rhodesia Agricultural, 67, 61-64.

[13] Gyawali, S., Sunwar, S., Subedi, M., Tripathi, M., Joshi, K.D. and Witcombe, J.R. (2007) Collaborative Breeding with Farmers Can Be Effective. Journal of Field Crops Research, 101, 88-95. https://doi.org/10.1016/j.fcr.2006.09.013

[14] Brady, N.C. and Weil, R.R. (2010) The Nature and Properties of Soils. 13th Edition, Prentice Hall, Upper Saddle River.

[15] Food and Agriculture Organization (FAO) (2005) Fertilizer Use by Crop in Ghana. Land and Plant Nutrition Management Service: Land and Water Development Division. Food and Agriculture Organization of the United Nations, Rome, 40.

[16] Marschner, H. (2012) Mineral Nutrition of Higher Plants. Academic Press, San Diego.

[17] Ayodele, O.J. and Oso, A.A. (2014) Cowpea Responses to Phosphorus Fertilizer Application at Ado-Ekitti, South-West Nigeria. Journal of Applied Science in Agricutlture, 9, 485-489.

[18] Thiago, P.F., Andre, T., Bruno, L.S. and Fatima, M.S.M. (2015) Inoculation and Liming Increase Cowpea Productivity in Marahao State. Journal of Science in Agronomy, 38, 387-395. https://doi.org/10.4025/actasciagron.v38i3.28630

[19] Okanya, J.S. and Mass, B.L. (2014) Protein and Iron Composition of Cowpea Varieties Grown in Eastern Africa. African Journal of Food, Agriculture, Nutrition and Development, 14, 2130-2140. http://ajfand.net/AJFAND/copyrightstatement.html

[20] Katherine, M., Andrew, J.M., Apangu, T., Griffith, K.S., Mead, P.S., Acayo, S., Acidri, R., Moore, S.M., Tendomapange, J., Ensore, R.E., Keneth, L.G. and Rebecca, J.E. (2012) Climate Predictors of the Spatial Distribution of Human Plague Cases in the West Nile Region of Uganda. Journal of American Society of Tropical Medicine and Hygiene, 86, 514-523. https://doi.org/10.4269/ajtmh.2012.11-0569

[21] Nkaa, F.A., Nwokeocha, O.W. and Ihuoma, O. (2014) Effect of Phosphorus Fertilizer on Growth and Yield of Cowpea (Vigna Unguiculata L. Walp). Journal of Pharmaceutical, Biology Sciences, 9, 74-82.

[22] Ssekabembe, C.K. (2010) Introduction to Agronomy, Principles and Practices. Fountain Publishers, Uganda.

[23] Anderson, J.M. and Ingram, J.S.L. (1993) Tropical Soil Biology and Fertility. A Hand Book of Methods. 2nd Edition, Oxford University Press, Wallingford.

[24] Warncke, D., Dahl, J., Jacobs, L. and Laboski, C. (2004) Nutrient Recommendation 
for Field Crops in Michigan University. Extension Bulletin E2904, Michigan State University (MSU), Michigan.

[25] Ahmed, M., Naim, E., Abderlrhim, A., Jabereldar, A., Salaheldeen, E., Ahmed, IM. and Elshieth, A.I. (2012) Determination of Sustainable Variety Per Stand of Cowpea (Vigna unguiculata L.Walp) in the Sandy Soil, Sudan. Journal of Advances in Life Sciences, 2, 1-5. https://doi.org/10.5923/j.als.20120201.01

[26] Barron, J., Rockstrom, G.F. and Haitbu, N. (2003) Dry Spell Analysis and Maize Yields for Two Semi-Arid Locations in East Africa. Journal of Agricultural Meteorology, 117, 23-37. https://doi.org/10.1016/S0168-1923(03)00037-6

[27] Ajayi, S.A., Obolade, O.F., Adetumbi, J.A., Adeniyan, O.N. and Ogunbodede, B.A. (2012) Plating Date Affects Cowpea Seed Yield and Quality in Southern Guinea Savanna, Nigeria. Journal of Agriculture and Environment, 2, 63-168.

[28] Karikari, B., Arkoful, E. and Andy, S. (2015) Growth, Nodulation and Yield Response of Cowpea to Phosphorus Fertilizer Application in Ghana. Journal of Agronomy, 14, 234-240. https://doi.org/10.3923/ja.2015.234.240

[29] Adriana, M. (2000) Overview and Case Studies of Biological Nitrogen Fixation. Perspectives and Limitations a Report on Collection of Nitrogen fixing Bacterial Legume Symbionts. University of Reading. Faculty of Agriculture and Food Sciences Department of Soil Science, Thesis in University of Ibadan, Nigeria.

[30] Agboola, A.A. and Obigesan, G.H. (1977) Effect of Different Sources of Levels of P on the Performance of P Uptake of Ife-Brown Variety of Cowpea in Ghana. Journal of Agricultural Science, 10, 71-75. http://www.academicjournals.org/AJB

[31] Saginga, N., Lyasse, O. and Singh, B.B. (2000) Phosphorus Use Efficiency and Nitrogen Balance of Cowpea Breeding Lines in a Low P Soil of the Derived Savannah Zone in West Africa. Journal of Plant Soil, 220, 119-128.

https://doi.org/10.1023/A:1004785720047 